\title{
Progress in molecular profiling: new recommendations in myelodysplastic syndromes
}

\author{
Jan Styczyński iD \\ Department of Pediatric Hematology and Oncology, Collegium Medicum in Bydgoszcz, Nicolaus Copernicus University in Toruń, \\ Jurasz University Hospital 1, Bydgoszcz, Poland
}

Myelodysplastic syndromes (MDS) are highly heterogeneous disorders characterised by the presence of ineffective hematopoiesis with peripheral blood cytopenias, dysplastic changes in $\geq 10 \%$ of cells in one or more myeloid lineages, and a variable risk of progression to acute myeloid leukemia (AML) [1].

With the rapid development of molecular biology over recent years, significant progress has been made in understanding the genetic characteristics of MDS. Although molecular tests are not included in the diagnostic standard in MDS, many studies have confirmed the predictive and prognostic impact of a number of mutations in patients with this diagnosis. Such knowledge highlights a clear path towards the development of targeted therapies. Today, numerous trials are running all over the world aimed at the use of targeted therapies in higher risk MDS. Additionally, significant progress has been made in therapy of lower risk MDS, especially for those who are transfusion-dependent.

In this issue of "Acta Haematologica Polonica", Mądry et al. [2] present new Polish recommendations for the diagnostics of MDS. This will be followed by recommendations on MDS treatment to appear in the next issue of "Acta Haematologica Polonica" [3]. These recommendations are in line with our journal's policy of international cooperation in hematology [4-10].

\section{Authors' contributions \\ JS - sole author.}

\section{Conflict of interest}

Nothing to disclose.

\section{Financial support}

No financial support.

\section{Ethics}

The work described in this article has been carried out in accordance with The Code of Ethics of the World Medical Association (Declaration of Helsinki) for experiments involving humans; EU Directive 2010/63/EU for animal experiments; uniform requirements for manuscripts submitted to biomedical journals.

\section{References}

1. Arber DA, Orazi A, Hasserjian R, et al. The 2016 revision to the World Health Organization classification of myeloid neoplasms and acute leukemia. Blood. 2016; 127(20): 2391-2405, doi: 10.1182/ blood-2016-03-643544.

2. Mądry K, Drozd-Sokołowska J, Lis K, et al. Diagnosis of myelodysplastic syndromes in Poland: the Polish Adult Leukemia Group (PALG) 2021 recommendations. Acta Haematol Pol. 2022; 53(1): 3-18, indexed in Pubmed: 10.5603/AHP.a2022.0001.

3. Mądry K, Budziszewska BK, Lis K, et al. Treatment of myelodysplastic syndromes in Poland: the Polish Adult Leukemia Group (PALG) 2021 recommendations. Acta Haematol Pol. 2022; 53(2), doi: 10.5603/ AHP.a2022.0007.

4. Giebel S, Basak G, Bieniaszewska M, et al. Current status and progress of Polish hemato-oncology. Acta Haematol Pol. 2021; 52(1): 4-17, doi: 10.5603/AHP.2021.0003.

5. Antoniewicz-Papis J, Brojer E, Fabijańska-Mitek J, et al. Current status and achievements of Polish transfusion medicine. Acta Haematol Pol. 2021; 52(3): 147-162, doi: 10.5603/AHP.2021.0031.

6. Gil L, Kałwak K, Piekarska A, et al. Antifungal management in adults and children with hematological malignancies or undergoing hematopoietic cell transplantation: recommendations of Polish Society of Hematology and Blood Transfusion, Polish Society of Pediatric Oncology and Hematology, and Polish Adult Leukemia Study Group, 2020. Acta Haematol Pol. 2020; 51(2): 60-72, doi: 10.2478/ahp2020-0014.

\footnotetext{
*Address for correspondence: Jan Styczyński, Department of Pediatric Hematology and Oncology, Collegium Medicum, Nicolaus Copernicus University Toruń, Skłodowskiej-Curie 9, 85-094 Bydgoszcz, Poland, phone +48 5258548 60, fax +48 5258540 87, e-mail: jstyczynski@cm.umk.pl Received: 19.12.2021 Accepted: 19.12 .2021
}
PTHiT Copyright (๑) 2022 The Polish Society of Haematologists and Transfusiologists, Insitute of Haematology and Transfusion Medicine. All rights reserved. load articles and share them with others as long as they credit the authors and the publisher, but without permission to change them in any way or use them commercially. 
7. Styczynski J, Tridello G, Gil L, et al. Prognostic impact of Epstein-Barr virus serostatus in patients with nonmalignant hematological disorders undergoing allogeneic hematopoietic cell transplantation: the study of Infectious Diseases Working Party of the European Society for Blood and Marrow Transplantation. Acta Haematol Pol. 2020; 51(2): 73-80, doi: 10.2478/ahp-2020-0015.

8. Czyżewski K, Sedláček P, Štěrba J, et al. Progress and trends in pediatric hematopoietic cell transplantation in Central-East European countries. Acta Haematol Pol. 2020; 51(3): 142-150, doi: 10.2478/ ahp-2020-0026.
9. Jurczyszyn A, Charliński G, Suska A, et al. The importance of cytogenetic and molecular aberrations in multiple myeloma. Acta Haematol Pol. 2021; 52(4): 361-370, doi: 10.5603/AHP.2021.0069.

10. Snowden JA, Styczyński J, Snarski E, et al. Hematopoietic stem cell transplantation in autoimmune diseases: update from EBMT Autoimmune Diseases Working Party with special reference to and. Acta Haematol Pol. 2021; 52(4): 217-224, doi: 10.5603/ AHP.2021.0043. 